Article - Biological and Applied Sciences

\title{
Influence of Silver Nitrate on Somatic Embryogenesis Induction in Arabica Coffee (Coffea arabica L.)
}

Laura Rojas-Lorz ${ }^{1}$

http:// orcid.org/0000-0003-3688-9131

Griselda Arrieta-Espinoza ${ }^{2}$

http:// orcid.org/0000-0001-9235-5834

Marta Valdez-Melara ${ }^{1}$

http:// orcid.org/0000-0001-5582-0143

Luiz Filipe Protasio Pereira ${ }^{34}$

http:// orcid.org/0000-0002-4872-6607

\section{Andrés Gatica-Arias ${ }^{1 *}$}

http:// orcid.org/0000-0002-3841-0238

${ }^{1}$ University of Costa Rica, School of Biology, Laboratory of Plant Biotechnology, San José, Costa Rica; ${ }^{2}$ University of Costa Rica, Research Center in Cellular and Molecular Biology (CIBCM), San José, Costa Rica; ${ }^{3}$ Agronomic Institute of Paraná (IAPAR), Plant Biotechnology Laboratory, Londrina, Brazil; ${ }^{4}$ Brazilian Agricultural Research Corporation (Embrapa Café), Brasília, Brazil.

Received: 2018.05.08; Accepted: 2019.06.11.

* Correspondence: andres.gatica@ucr.ac.cr; Tel.: +506-2511-8656

\section{HIGHLIGHTS}

- LFSE offers a simple and rapid way for somatic embryo and plant conversion.

- Somatic embryos is favored by the addition of $\mathrm{AgNO}_{3}$.

- Somatic embryos were induced using leaf sections of in vitro plants within 8 weeks.

Abstract: The influence of silver nitrate (AgNO3), benzyladenine (BAP), and indole-3-acetic acid (IAA) on low frequency somatic embryogenesis (LFSE) induction in Caturra and Catuaí arabica coffee was evaluated. For the Caturra cultivar, the production of somatic embryos was significantly increased by adding $\mathrm{AgNO} 3$ to the semisolid culture medium. The highest average number of somatic embryos for this cultivar was obtained using $6.6 \mu \mathrm{M}$ BAP, 2.85 $\mu \mathrm{M} I \mathrm{AA}$, and $40 \mu \mathrm{M}$ AgNO3. In contrast, for the Catuaí cultivar, the highest average number 
of somatic embryos was obtained using semisolid medium supplemented with $8.8 \mu \mathrm{M} \mathrm{BAP}$, and $2.85 \mu \mathrm{M}$ IAA. Using these protocols, somatic embryos were directly induced using leaf sections of in vitro plants of both coffee cultivars within 8 weeks. The somatic embryos developed into rooted plants with a $100 \%$ survival rate upon transfer to the greenhouse.

Keywords: coffee; silver nitrate; somatic embryos; plant growth regulators; tissue culture.

\section{INTRODUCTION}

Plant somatic embryogenesis (SE) has been defined as the formation of embryos from a single or group of haploid or somatic cells [1, 2]. Low frequency (LFSE) and high frequency somatic embryogenesis (HFSE) have been described. In the first type, somatic embryos are induced directly from pro-embryogenic cells of explants, while in the second, they originate from embryogenic callus [1]. It has been suggested that in LFSE the origin of somatic embryos is unicellular, whereas in HFSE has been described as unicellular or multicellular [3]. SE is a powerful biotechnological tool used to propagate elite plants or to conserve important genotypes [4]. Moreover, SE offers an efficient in vitro regeneration approach as a fundamental step in plant genetic improvement for studying basic aspects of ontogenesis of somatic embryos [5]. In Coffea spp., the first studies of SE have been reported at the beginning of 1970 [6]. Since then, a large quantity of LFSE and HFSE protocols have been optimized demonstrating that coffee is not a recalcitrant species for SE [4]. In the LFSE the somatic embryos are obtained faster (approximately 70 days) using only one medium meanwhile in HFSE several media are used and somatic embryo formation takes 9-10 months [4]. Although, in LFSE small number of somatic embryos are obtained (around 10 per explant) compared to hundreds of somatic embryos obtained per gram of embryogenic calli [4], the unicellular origin of somatic embryos in LFSE represents an advantage for the chemical and physical mutagenesis, genetic transformation and genetic editing, since prevents or reduces the appearance of chimeras [7]. In C. arabica and $C$. canephora many factors (such as genotype, explant type, the physiological state, age and growth conditions of the donor plants, the season of collection, nutrient composition of the medium, the volume of dissolved $\mathrm{CO}_{2}$ or $\mathrm{O}_{2}$ in the culture flask, and plant growth regulators) that affect LFSE induction have been studied [3, 8, 9, 10, 11, 12, 13]. However, few studies reported the effect of silver nitrate on LFSE using leaf explants of $C$. arabica $L$. and to the best of our knowledge it has not been analyzed using Caturra and Catuaí, which are two economic important producer cultivars in Costa Rica. Since SE is genotype dependent, the culture medium need to be modified for the different genotypes [7].Therefore, the objective of this study was to determine the influence of the benzyladenine (BAP), indole-3-acetic acid (IAA), and silver nitrate $\left(\mathrm{AgNO}_{3}\right)$ on low frequency somatic embryogenesis using leaf explants of Coffea arabica L. cultivars Caturra and Catuaí.

\section{MATERIAL AND METHODS}

In vitro coffee (Coffea arabica L. cvs. Caturra and Catuaí.) plants were used as explant donors. Leaf sections $\left(0.5 \mathrm{~cm}^{2}\right)$ without midveins or margins were cultured in disposable petri dishes $(94 \times 16 \mathrm{~mm})$ with the adaxial side in contact with $20 \mathrm{ml}$ of MS medium [14] (Phytotechnology Laboratories) supplemented with $30 \mathrm{gL}^{-1}$ sucrose, BAP, IAA, and $\mathrm{AgNO}_{3}$ at the concentrations listed in Table 1 [15]. Cultures were maintained at $26 \pm 2{ }^{\circ} \mathrm{C}$ with a $16 \mathrm{~h}$ photoperiod $\left(30 \mu \mathrm{mol} . \mathrm{m}^{-2} \cdot \mathrm{s}^{-1}\right)$. One hundred leaf disks were evaluated per treatment. The number of somatic embryos per explant was recorded after 8 weeks of culture. Statistical analysis was performed using one-way ANOVA and means were compared with Duncan's Test at $p=0.05$ using the program InfoStat [16]. Morphological features of the somatic embryos were determined using a histological analysis [17]. Globular embryos were transferred to baby food jars containing $20 \mathrm{~mL}$ of MS medium (Phytotechnology 
Laboratories) supplemented with $6.6 \mu \mathrm{M}$ BAP, $2.85 \mu \mathrm{M}$ IAA, $40 \mu \mathrm{M} \mathrm{AgNO}$, and $30 \mathrm{gL}^{-1}$ sucrose. Jars were sealed with plastic wrap. Cultures were maintained at $26 \pm 2^{\circ} \mathrm{C}$ with a $16 \mathrm{~h}$ light photoperiod $\left(30 \mu \mathrm{mol} . \mathrm{m}^{-2} \cdot \mathrm{s}^{-1}\right)$. The growth regulators and $\mathrm{AgNO}_{3}$ used in the study were obtained from Sigma, St. Louis, MO, USA. The media pH was adjusted to 5.6 and the media was gelled with $8 \mathrm{gL}^{-1}$ agar (Phytotechnology Laboratories) before autoclaving at $121^{\circ} \mathrm{C}$ for $21 \mathrm{~min}$. Regenerated plantlets were washed with water and transferred to pots containing autoclaved peat substrate (Plug Mix Perlite, VJ Centroamericana, San José, Costa Rica) and grown in the greenhouse at $18-35^{\circ} \mathrm{C}$ with a $12 \mathrm{~h}$ photoperiod and $80 \%$ relative humidity.

\section{RESULTS}

In this work, the effect of BAP, IAA, and $\mathrm{AgNO}_{3}$ on LFSE induction in Caturra and Catuaí cultivars was evaluated (Table 1). For the Caturra cultivar, the formation of somatic embryos was significantly superior on culture medium with added $\mathrm{AgNO}_{3}$ than on medium devoid of this compound (Figure 1). Somatic embryo production was lower at BAP concentrations of $8.8 \mu \mathrm{M}$ and $11.1 \mu \mathrm{M}$ than $6.6 \mu \mathrm{M}$ in treatments with added $\mathrm{AgNO}_{3}$ (Table 1). On the other hand, the complementation of the culture medium with $\mathrm{AgNO}_{3}$ did not stimulate the production of somatic embryos in the Catuaí cultivar (treatment E) (Figure 2D, 2E, and 2F), indicating that the response to $\mathrm{AgNO}_{3}$ was dependent on genotype. The highest average of somatic embryos for this cultivar was obtained on semisolid medium supplemented with 8.8 $\mu \mathrm{M}$ BAP and $2.85 \mu \mathrm{M}$ IAA (Figure 2B) (Table 1). Somatic embryos did not form in either cultivar on culture medium devoid of BAP, IAA, and $\mathrm{AgNO}_{3}$ (treatment A) (Table 1).

Table 1. Effect of BAP, IAA, and $\mathrm{AgNO}_{3}$ on direct somatic embryogenesis in leaf explants of Caturra and Catuaí vitroplants after 8 weeks of culture.

\begin{tabular}{|c|c|c|c|c|c|}
\hline & \multicolumn{3}{|c|}{ Treatments $(\mu \mathrm{M})$} & \multicolumn{2}{|c|}{$\begin{array}{l}\text { Number of somatic embryos per explant } \\
\text { (mean } \pm \text { SE) }\end{array}$} \\
\hline & BAP & IAA & $\mathrm{AgNO}_{3}$ & Caturra & Catuaí \\
\hline$A$ & - & - & - & $0 \pm 0 \quad c^{1}$ & $0 \pm 0 \quad d$ \\
\hline B & 6.6 & 2.85 & - & $0.3 \pm 0.3 \mathrm{c}$ & $0.4 \pm 0.2 \mathrm{c} \mathrm{d}$ \\
\hline C & 6.6 & 2.85 & 40 & $3.3 \pm 0.3 a$ & $1.2 \pm 0.2 b$ \\
\hline D & 8.8 & 2.85 & - & $0.4 \pm 0.3 c$ & $2.4 \pm 0.2 \mathrm{a}$ \\
\hline$E$ & 8.8 & 2.85 & 40 & $2.3 \pm 0.3 b$ & $1.0 \pm 0.2 b c$ \\
\hline $\mathrm{F}$ & 11.1 & 2.85 & - & $0 \pm 0 \quad c$ & $0.8 \pm 0.2 b c$ \\
\hline G & 11.1 & 2.85 & 40 & $2.4 \pm 0.2 b$ & $0.7 \pm 0.2 b c$ \\
\hline
\end{tabular}

${ }^{1}$ Means followed by the same letter are not significantly different at $p=0.05$ using Duncan's test.

During the LFSE process, four developmental stages of Caturra somatic embryos were observed (Figure 3). Globular-shaped somatic embryos were bright (Figure 3A) and their cells showed a prominent nucleus and a dense cytoplasm. A suspensor-like structure connected the globular embryos with parent explants (Figure 3B). Heart-shaped embryos showed a well-defined procambium and a notch on the tip (Figure 3C and 3D). Torpedo stage somatic embryos (Fig. 3E) showed a distinct procambium (Figure 3F). Finally, the torpedo stage somatic embryos formed small plantlets with distinct cotyledon leaves, apical shoots and root meristems (Figure 3G). The cotyledon primordia formation began with the division of the procambium in the shoot axis (Figure $3 \mathrm{H}$ ).

Using the protocol described here, it was possible to induce somatic embryos directly from leaf sections of in vitro plants of both coffee cultivars within 8 weeks. The somatic embryos developed into rooted plants with a survival rate of $100 \%$ upon transfer to the 
greenhouse. In this study, the induction of somatic embryos, development of plants and greenhouse acclimatization of in vitro culture plantlets required 14 months. A protocol for LFSE induction from leaf segments of $C$. arabica L. Cv Caturra to acclimatization of in vitro culture plantlets in the greenhouse is shown in Figure 4.

\section{DISCUSSION}

Several factors influence SE in coffee, including genotype, explant type, the physiological state, age and growth conditions of the donor plants, the season of collection, nutrient composition of the medium, the volume of dissolved $\mathrm{CO}_{2}$ or $\mathrm{O}_{2}$ in the culture flask, and plant growth regulators [4,5].

Similarly to our results, previous studies have demonstrated that silver nitrate (30-60 $\mu \mathrm{M})$ stimulates organogenesis and SE in C. canephora [18, 19], C. dewevrei [12], C. arabica [19]. In this sense, a possible explanation of the positive effect of $\mathrm{AgNO}_{3}$ could be that this compound promotes in vitro regeneration by inhibiting ethylene action and limiting explant oxidation and necrosis. Moreover, the inhibition of ethylene production has positive effects by enhancing the biosynthesis of polyamines, which participate in growth and development of plants as well as in basic biological process [20]. Likewise to the results of the present work, previous studies have demonstrated that coffee somatic embryogenesis is promoted by the combined use of auxins and cytokines [4,5]. Similarly to our results, the formation of somatic embryos was favored by the combination of BAP, IAA, and $\mathrm{AgNO}_{3}$ in $C$. dewevrei [16] and C. arabica and C. canephora [19].

Similar histological studies in coffee indicated that low frequency somatic embryo formation from leaf segments began with the rapid division and proliferation of the most mitotically active subepidermal cell layers. In this sense, it has been reported that small, isodiametric, densely cytoplasmic cells suffered a series of organized divisions originating somatic embryos [3, 17].

As previously reported in coffee, somatic embryos are obtained quicker using LFSE (about 7-12 weeks) than HFSE [4, 17, 21].

\section{CONCLUSION}

A protocol for LFSE was presented for simple and rapid formation of somatic embryo and plant conversion from leaf explants of Caturra and Catuaí using BAP, IAA and $\mathrm{AgNO}_{3}$. This protocol does not involve the formation of embryogenic callus. The faster response provides a new scenario for coffee genetic modification.

Funding: This research was funded by the University of Costa Rica and MKTPLACE (project No. 111-B3-206).

Conflicts of Interest: The authors declare no conflict of interest. The funders had no role in the design of the study; in the collection, analyses, or interpretation of data; in the writing of the manuscript, or in the decision to publish the results.

\section{REFERENCES}

1. Jiménez, VM. Regulation of in vitro somatic embryogenesis with emphasis on the role of endogenous hormones. Rev. Bras. Fisiol. Veg. 2001; 13, pp. 196-223.

2. Jiménez, VM. Involvement of plant hormones and plant growth regulators on in vitro somatic embryogenesis. Plant Growth Regul. 2005; 47, pp. 91-110.

3. Quiroz-Figueroa, F.R.; Fuentes-Cerda, C.F.J.; Rojas-Herrera, R.; Loyola-Vargas, V.M. Histological studies on the developmental stages and differentiation of two different somatic embryogenesis systems of Coffea arabica. Plant Cell Reps. 2002; 20, pp. 1141-1149.

4. Campos, N.A; Panis, B.; Carpentier, S.C. Somatic embryogenesis in coffee: The evolution of biotechnology and the integration of omics technologies offer great opportunities. Front. Plant Sci. 2017; 8, pp. 1460. 
5. Loyola-Vargas, V.M.; Avilez-Montalvo, J.R.; Avilés-Montalvo, R.N.; Márquez-López, R.E.; Galaz-Ávalos, R.M.; Mellado-Mojica, E. Somatic embryogenesis in Coffea spp. In: Loyola-Vargas VM and Ochoa-Alejo N (eds.) Somatic embryogenesis: Fundamental Aspects and Applications; Switzerland: Springer International Publishing 2016

6. Jain, S. In vitro mutagenesis for improving date palm (Phoenix dactylifera L.). Emirates J. Food Agric. 2012; 24, pp. 400-407.

7. Loyola-Vargas, V.M. The history of somatic embryogenesis. In: Loyola-Vargas VM and Ochoa-Alejo N (eds.) Somatic Embryogenesis: Fundamental Aspects and Applications; Switzerland: Springer International Publishing 2016

8. Dublin, P. Embryogenèse somatique directe sur fragments de feuilles de caféir Arabusta.- Café Cacao The. 1981; 25, pp. 237-242.

9. Yasuda, T.; Fujii, Y.; Yamaguchi, T. Embryogenic callus induction from Coffea arabica leaf explant by benziladenine. Plant Cell Physiol. 1985; 26, pp. 595-597.

10. Hatanaka, T.; Arakawa, O.; Yasuda, T.; Uchida, N.; Yamaguchi, T. Effect of plant growth regulators on somatic embryogenesis in leaf cultures of Coffea canephora. Plant Cell Rep. 1991; 10, pp. 179-182.

11. Bieysse, D.; Gofflot, A.; Michaux-Ferriere, N. Effect of experimental conditions and genotypic variability on somatic embryogenesis in Coffea arabica. Can. J. Bot. 1993; 71, pp. 1496-1502.

12. Molina, D.; Aponte, M.; Cortina, H.; Moreno, G. The effect of genotype and explant age on somatic embryogenesis of coffee. Plant Cell Tiss. Org. Cult. 2002; 71, pp. 117-123.

13. Giridhar, P.; Indu, E.P.; Ravishankar, G.A.; Chandrasekar, A. Influence of TRIA on somatic embryogenesis in Coffea arabica L. and Coffea canephora P. EX FR. In Vitro Cell. Dev. Biol. 2004; 40, pp. 200-203.

14. Murashige, T.; Skoog, F. A revised medium for rapid growth and bioassays with tobacco tissue cultures. Physiol. Plant. 1962; 15, pp. 473-497.

15. Sridevi, V.; Giridhar, P. In vitro shoot growth, direct organogenesis and somatic embryogenesis promoted by silver nitrate in Coffea dewevrei. J. Plant Bioch.Biotechnol. 2012; 23, pp. 112-118.

16. Di Rienzo, J.A.; Casanoves, F.; Balzarini, M.G.; Gonzalez, L.; Tablada, M.; Robledo, C.W. InfoStat. Universidad Nacional de Córdoba: España; 2011.

17. Gatica-Arias, A.M.; Arrieta, G.; Espinoza, A.M. Comparison of three in vitro protocols for direct somatic embryogenesis and plant regeneration of Coffea arabica L. cvs. Caturra and Catuaí. Agronomía Costarricense. 2007; 31, pp. 85-94.

18. Fuentes, S.; Calheiros, M.; Manetti-Filho, J.; Vieira, L. The effects of silver nitrate and different carbohydrate sources on somatic embryogenesis in Coffea canephora. Plant Cell Tiss. Org. Cult. 2000; 60, pp. 5-13.

19. Giridhar, P.; Indu, E.P.; Vinod, K.; Chandrashekar, A.; Ravishankar, G.A. Direct somatic embryogenesis from Coffea arabica L. and Coffea canephora P ex Fr. under the influence of ethylene action inhibitor-silver nitrate. Acta Physiol. Plant. 2004; 26, pp. 299-305.

20. Kumar, G.P.; Sivakumar, S.; Siva, G.; Vigneswaran, M.; Kumar, T.S.; Jayabalan, N. Silver nitrate promotes high-frequency multiple shoot regeneration in cotton (Gossypium hirsutum L.) by inhibiting ethylene production and phenolic secretion. In Vitro Cell. Dev. Biol. Plant 2016; 52, pp. 408-418.

21. Gatica-Arias, A.M.; Arrieta, G.; Espinoza, A.M. Direct somatic embryogenesis in Coffea arabica L.: effect of triacontanol, light condition and medium consistency. Agronomía Costarricense. 2008; 32: 139-147.

(c) 2018 by the authors. Submitted for possible open access publication under the terms and conditions of the Creative Commons Attribution (CC BY NC) license (https://creativecommons.org/licenses/by-nc/4.0/). 